\title{
A significação em Portais e a Abside, de Celso Loureiro Chaves
}

\author{
Flávio Santos Pereira (UnB, Brasília, DF) \\ f_santospereira@hotmail.com
}

Resumo: Neste artigo empreende-se a análise da obra Portais e a Abside, de Celso Loureiro Chaves, para violão solo, de 1997. A análise segue os princípios da nova musicologia, como têm sido postos em prática por autores como Lawrence Kramer e Rose Subotnik. 0 ponto de partida e permanente referência da análise são as evidências deixadas pelo próprio compositor: o caráter inteiramente serial da obra; a relação do esquema formal da obra com "o plano arquitetônico de um templo imaginário, mas que poderia estar localizado na ilha de Próspero tal como desenhada por Peter Greenaway para o seu filme $A$ Última Tempestade"; a referência da seção central da peça à memória de "alguma leitura longinqua da obra Grande Sertão: Veredas, de Guimarães Rosa". A partir destas evidências busca-se intuir um contexto que ilumine a obra e desvele a profundidade do seu significado.

Palavras-chave: análise musical; musicologia cultural; música e sociedade; Celso Loureiro Chaves; repertório brasileiro para violão.

\section{Significance in Portals and the Apse by Celso Loureiro Chaves}

Abstract: An analysis of the solo guitar piece Portals and the Apse by Celso Loureiro Chaves (1997) is undertaken in this article. The analysis follows the principles of the new musicology, as put into practice by authors such as Lawrence Kramer and Rose Subotnik. The starting point of the analysis and its guiding line are the evidences left behind by the composer, namely the entirely serial nature of the work; the relationship of its formal scheme with "the architectural plan of an imaginary temple, that could be located on Prospero's island as drawn by Peter Greenaway for his film Prospero's Books "; the reference of the central section of the work to the memory of a "distant reading of the novel The Devil to Pay in the Backlands, by Guimarães Rosa." From these evidences we seek to draw a context that aims at illuminating the work and unveiling the depth of its meaning.

Keywords: musical analysis; new musicology; music and society; Celso Loureiro Chaves; Brazilian repertoire for guitar.

\footnotetext{
O terceiro impasse [da musicologia] é o do comentário estético. No seu conjunto, a abundante literatura consagrada às sonatas, quartetos e sinfonias soa vazia. Somente o hábito pode mascarar-nos a pobreza e o caráter disparatado dessas análises. Pondo-se de parte a montante e a jusante da obra, as considerações complacentes sobre os estados de alma do compositor ou do exegeta, vemo-nos condenados a mais árida enumeração, em termos de tecnologia musical, dos seus procedimentos de construção, ou, no melhor dos casos, ao estudo da sua sintaxe. Nenhuma verdadeira explicação do texto. Mas talvez não haja motivo de espantar-se por isso. Não poderia a boa música, sendo ela uma linguagem - e linguagem específica -, escapar radicalmente a toda descrição e a toda explicação por meio de palavras? Melhor seria confessar, em resumo, que não sabemos grande coisa sobre a música.1 (SCHAEFFER, tradução de MARTINAZZO, 1993, p.30-31)
}

\section{1 - Introdução}

Permanecem, ainda hoje, não resolvidas questões fundamentais da análise musical. Pratica-se ainda uma análise que desconsidera completamente o pertencimento da obra ao seu tempo, voltada exclusivamente para o interior e, ao mesmo tempo, limitada - poder-se-ia dizer fisicamente - pelo objeto musical. Esta prática analítica objetiva foi paradoxalmente adotada tanto pelos movimentos mais conservadores quanto pela assim denominada vanguarda musical. Pelo conservadorismo musical como método de demonstração do valor superior e atemporal da música tonal do final do barroco até o romantismo de Brahms, propósito e ideologia do método analítico de Schenker que vislumbra na redução da obra inteira ao movimento primordial tônica- 
dominante-tônica a evidência da perfeição, como, é nosso pensamento, fica evidente de seus gráficos analíticos, especialmente em seu Five Graphic Music Analyses (SCHENKER, 1969). Pela vanguarda musical, esta prática analítica objetiva foi adotada como uma das bandeiras contra uma interpretação musical apoiada em impressões subjetivas, como uma reação à ideologia romântica, como é o caso, dentre inúmeros exemplos, da análise arquetípica que faz Boulez (1953) da rítmica da Sagração da Primavera em Stravinsky permanece, análise em que interroga admiradores e detratores se "Não seria mais sério ocuparem-se de Le Sacre enquanto produção musical e constatar em que domínio podemos nos dedicar a uma exploração rendosa depois de nos descartarmos de certo vocabulário exclamativo, sentimental e perigosamente pítico ao qual não parece querer renunciar a exegese musical?" (BOULEZ, 1995, p.75-76). Na mesma linha de pensamento, ao abordar o fenômeno rítmico em Proposições Boulez (1948) manifesta "o horror de tratar verbalmente o que se designa, com indulgência, problema estético" (BOULEZ, 1995, p.73). Esta prática nasceu da tentativa de se trazer para o universo da análise musical a objetividade e o rigor científico invejado em outras áreas do conhecimento. Chegou-se a pleitear o caráter autônomo da análise musical, a constituir-se como disciplina com objeto e metodologia próprios. É nesta direção, para ficarmos em alguns exemplos notórios, que apontam os trabalhos de lan Bent, Analysis (1980/1987); de Nicholas Cook, A Guide to Musical Analysis (1987); de Jonathan Dunsby e Arnold Whittall, Music Analysis in Theory and Practice (1988); de Allen Forte, The Structure of Atonal Music (1973). Mesmo Nicholas Cook (1987), quando preconiza que "Uma boa análise não meramente reflete e descreve a experiência, porém também tem a habilidade de nos fazer ouvir a música diferentemente", está implícito o ouvir "diferentemente" como 0 desenvolvimento, por meio da análise, da habilidade de reconhecer os componentes do organismo musical, de classificar e compreender a sintaxe musical, seja no nivel elementar do contraponto, da harmonia ou, de modo geral, da compreensão da sintaxe das alturas, seja no nível da forma e dos elementos que a determinam. "Nenhuma verdadeira explicação do texto", como diria SCHAEFFER (1966, p.19).

\section{2 - As implicações da musicologia cultural}

$\mathrm{Na}$ década de 90, com Lawrence Kramer (especialmente com as publicações de Music as Cultural Practice e Musical Meaning Toward a Critical History), Philip Brett, Susan McClary, Rose Subotnik, Richard Leppert, Carolyn Abbate, Gary Tomlinson (AGAWU, 2004), ganhou força a reação contra esta posição de pretensa objetividade, reconhecendo-se a importância do meio social para o conhecimento e compreensão da obra. Esta nova postura manifesta-se claramente na pergunta que se coloca SUBOTNIK (1990, p.xvi) como questão central de seu doutorado e pós-doutorado: "Qual era a relação entre a ópera Germânica e a sociedade Germânica na primeira metade do século XIX?" Para que se alcance uma resposta, exige-se que sejam transpostos os limites do objeto musical, que se investigue e se esclareça o contexto e o momento histórico em que a obra - instrumento de ação e interação de um autor - surgiu, realizou-se, agiu e que reações e consequências provocou. Para SUBOTNIK (1990, p.141142, tradução nossa), "a noção de uma íntima relação entre música e sociedade [...] é uma ideia que gera estudos cujo objetivo (ou ao menos um dos objetivos importantes) é articular algo essencial acerca de porque uma música em particular é do modo que é em especial, isto é, vislumbrar o caráter de sua identidade" ${ }^{2}$. A nova musicologia, ou, como o quer Kramer, a musicologia cultural - assim nominado o conjunto de autores engajados nesta nova perspectiva da abordagem do fenômeno musical - tem um objetivo "surpreendentemente modesto": "A ideia é combinar a visão estética em música com uma mais plena compreensão de suas dimensões cultural, social, histórica e política, além do que foi habitual na maior parte do século XX" ${ }^{3}$ (KRAMER, 2003, p.6, tradução nossa). 0 foco dessa expansão do objeto musical é o indivíduo, portador de subjetividade ${ }^{4}$, situado numa complexa rede de incessantes e múltiplas relações sociais. "Parece legítimo dizer que a musicologia cultural é, sobretudo, um esforço persistente para compreender a subjetividade musical na história." ${ }^{5}$ (KRAMER, 2003, p.6, tradução nossa) Passa-se, assim, a enxergar a obra musical inserida no meio social do qual esta é parte determinada e determinante. Percebese a importância das conexões externas à obra para a compreensão dela mesma. Esta nova postura traz consigo a consciência de que a análise é sempre parcial e jamais exaustiva: dá-nos conclusões que devem ser sempre retomadas e repensadas. Adotou-se, implicitamente, a noção da obra musical como fato social. Não se destruiu, muito ao contrário, a individualidade do artista e nem a singularidade da obra, mesmo quando efêmera. Antes, que a análise - superado o ingênuo conceito da objetividade do analista - estava obrigada, ao menos, a tentar abarcar todo o espaço social de onde surgia e onde se realizava a obra. Percebeu-se que esta, a obra de arte, só pode vir a se mostrar no seu pleno ser, no que contém de verdadeiro e legítimo, abordada como fenômeno social.

Esta postura, que ainda provoca fortes reações no meio musical, e que colocou em questão o caráter autônomo da obra de arte, obriga-nos a retomar em cada trabalho algumas questões fundamentais: 0 que expressa a obra de arte observada como objeto social, submetida primeira e inexoravelmente à apreciação do próprio artista, mas que pode encontrar em outro que não o seu criador o seu melhor decifrador? 0 que há do autor - ser social portador da subjetividade - na obra? Em que medida esta traz em si os paradoxos, conflitos e traços característicos do seu tempo? As questões são ambiciosas, mas as respostas são modestas, parciais e se enriquecem com o permanente questionamento. São, ao mesmo tempo, respostas que trazem informações muito mais profundas porque mostram, mesmo em conclusões parciais, o individuo e a sociedade impressos na obra musical. 


\section{3 - Portais e a Abside: primeiras considerações} É sob esta perspectiva, a da nova musicologia ou musicologia cultural - que não ignora a percepção fenomenológica, mas vê a obra no contexto mais amplo que a contém - que nos acercaremos de Portais e a Abside, de Celso Loureiro Chaves, para violão solo, de 1997. Tomaremos como ponto de partida a declaração do compositor - firmada no encarte do CD "I Paulo Inda", do intérprete Paulo Inda (2005) - de que a obra "é inteiramente serial", que o "Seu esquema formal reflete o plano arquitetônico de um templo imaginário, mas que poderia estar localizado na ilha de Próspero tal como desenhada por Peter Grennaway para o seu filme A Última Tempestade", e, por último, "A seção central da peça também traz memória de alguma leitura longinqua da obra Grande Sertão: Veredas, de Guimarães Rosa". Consideramos, por princípio, que o conjunto de referências é sempre muito mais amplo do que os indicados pelo artista criador. Abarcá-lo é um gesto impossivel que passa pelo periodo de concepção da obra até alcançar e ultrapassar o ser total do artista, que se coloca, momentaneamente, por inteiro em cada obra, principalmente o estar imerso e impregnado do seu tempo. Mas a geografia das referências indicadas pelo compositor já é extraordinariamente ampla. Faremos o esforço de desvelar algumas veredas: esta análise não pretende ser exaustiva, mas, antes, esclarecedora e orientadora do processo de escuta no seu sentido mais amplo, esclarecedora do sentido que a obra adquire em razão do seu pertencimento a um momento histórico especifico.

\section{4 - 0 serialismo em Portais e a Abside}

Iniciemos pela declaração de que a obra "é inteiramente serial", apesar de utilizar, como o diz o próprio compositor, "livremente rotações e séries multiplicativas". 0 pensamento serial se caracteriza por uma concepção ao mesmo tempo fragmentária e totalizante do som, desmembrando-o em parâmetros, e cada parâmetro fragmentando-se em unidades discretas reunidas primariamente em escalas. Cada parâmetro terá os termos de suas escalas submetidos a um ordenamento, que é a série propriamente dita. 0 rigor do ordenamento serial, muitas vezes reificado, é fortemente constrangedor da liberdade do artista, repressor da sua subjetividade, até então exacerbada pela ideologia romântica. A reação do compositor a este constrangimento do ordenamento serial será uma característica fundamental na demarcação dos estilos individuais. 0 pensamento serial - a começar por Schoenberg ${ }^{6}$, seu fundador - será marcado muito mais pelas estratégias de subversão do ordenamento do que pelo ordenamento serial propriamente dito. 0 princípio do ordenamento deu ao sistema serial um espírito de universalidade, mas as individualidades do compositor e da obra foram e são dados pelas estratégias de subversão do ordenamento mesmo. Em Portais e a Abside, na escrita, onde mais se emula a organização serial é na notação da dinâmica. Na percepção auditiva a dinâmica é de todos os parâmetros o menos apto a manifestar uma sistematização serial, em razão da pouca capacidade de se discriminar os termos da escala dinâmica adotada ou as unidades cardinais, para utilizarmos a terminologia de SCHAEFFER (1966). Este paradoxo entre uma notação dinâmica pontual e a impossibilidade do reconhecimento absoluto das respectivas unidades discretas, é resolvido em Portais e a Abside vinculando-se a detalhada indicação da dinâmica ao tratamento motívico e temático, onde cada elemento formal tem o seu próprio perfil dinâmico. $\mathrm{Ou}$, poderíamos dizer, onde cada perfil dinâmico tem o seu próprio material motívico. No plano das alturas e da rítmica, mesmo suportada a organização das alturas por uma sistematização serial, desdobra-se um discurso que é quase o de uma improvisação livre. A escrita do tempo, como no caso da dinâmica, simula também uma sistematização serial. Da mesma forma, na música serial se é confrontado com o problema da relativa incapacidade, ao nível da percepção auditiva, de se discriminar os termos da escala temporal adotada, $e_{\text {, }}$ consequentemente, com a impossibilidade de o tempo exercer as funções formais que Ihe são previamente designadas. Em Portais e a Abside o paradoxo entre uma notação rigorosa de um tempo inconstante e a impossibilidade de se perceber os seus valores absolutos resolve-se atribuindo à sistematização do tempo um claro papel na grande forma, associando as áreas de "instabilidade" do tempo às seções de transição. Há ainda a particularidade da notação do tempo em Portais e a Abside ser, a um só tempo, temporal, expressiva e gestual. Temos, por exemplo, em [B] seis distintas indicações de andamento - Scorrevole, Meno, Lento, Deciso, Strepitoso e Maestoso - às quais se associam, de fato, três indicações distintas de tempo - a semínima igual a 56, 59 e 62 . É da maior importância que o compositor reconheça na técnica serial um poderoso instrumento de organização, a ponto de assumir o pertencimento da obra ao domínio serial e declarar as suas estratégias de subversão, os seus instrumentos de individuação: o uso livre de rotações e séries multiplicativas.

\section{5 - Tema, motivo, elaboração, desenvolvimento, retórica}

Numa primeira audição, sobrepostos à organização serial, identificam-se à percepção como preceitos estruturantes fundamentais da composição do discurso os conceitos de tema, motivo, elaboração e desenvolvimento, característicos da tradição musical. Demonstramo-lo com a transcrição, Ex.1, do primeiro tema com que se inicia Portais e a Abside, e suas subsequentes transformações, onde se mantém 0 perfil dinâmico em forte e fortíssimo assim como, à exceção de em [I], a característica articulação rítmica: (Ex.1)

Ainda com relação à elaboração motívica, o motivo característico da seção central da obra, que aparece pela primeira vez no compasso 7 depois de [D], é deduzido do motivo rítmico final do tema inicial por meio da diminuição dos valores, Ex.2. Preserva-se nesta transformação o acento rítmico da colcheia, que, diminuida da metade do seu valor, recai na semicolcheia: (Ex.2) 

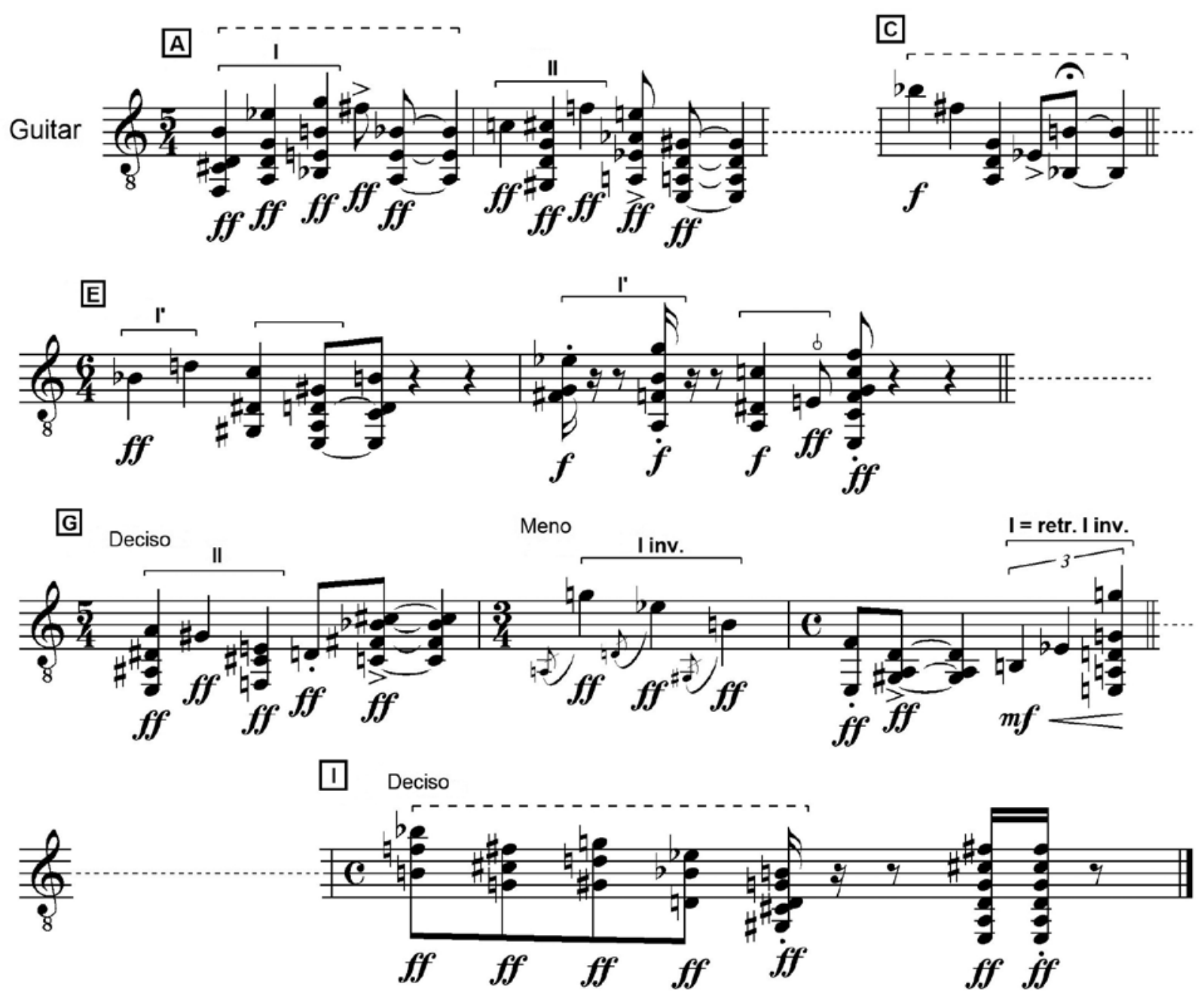

Ex.1. Primeiro tema e suas transformações: Em [C] e [I] temos o retrógrado da linha superior das alturas do tema em [A] c.1. 0 intervalo característico do motivo I, a terça maior - indicada como I' - inicia e articula a reapresentação do tema em [E]. A reiteração do tema em [A] c.2 é retomada em [G] com os mesmos intervalos melódicos da linha superior, semitom-terça maior, invertidos. Em [G] c.2, também invertido, retoma-se o motivo melódico inicial I do tema em $[A]$ c. 1 , que, retrógrado em relação ao compasso anterior, conclui esta reapresentação do tema. (Portais e a Abside de Celso Loureiro Chaves).

田 III c.7 depois de $\square$

Guitar
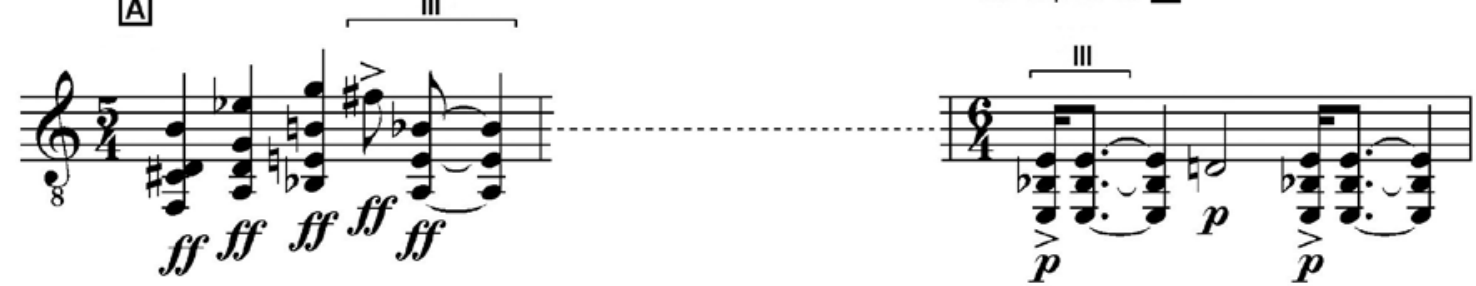

Ex.2. Elaboração motívica que associa, pela diminuição do ritmo, o primeiro tema com o motivo característico da seção central. (Portais e a Abside de Celso Loureiro Chaves) 

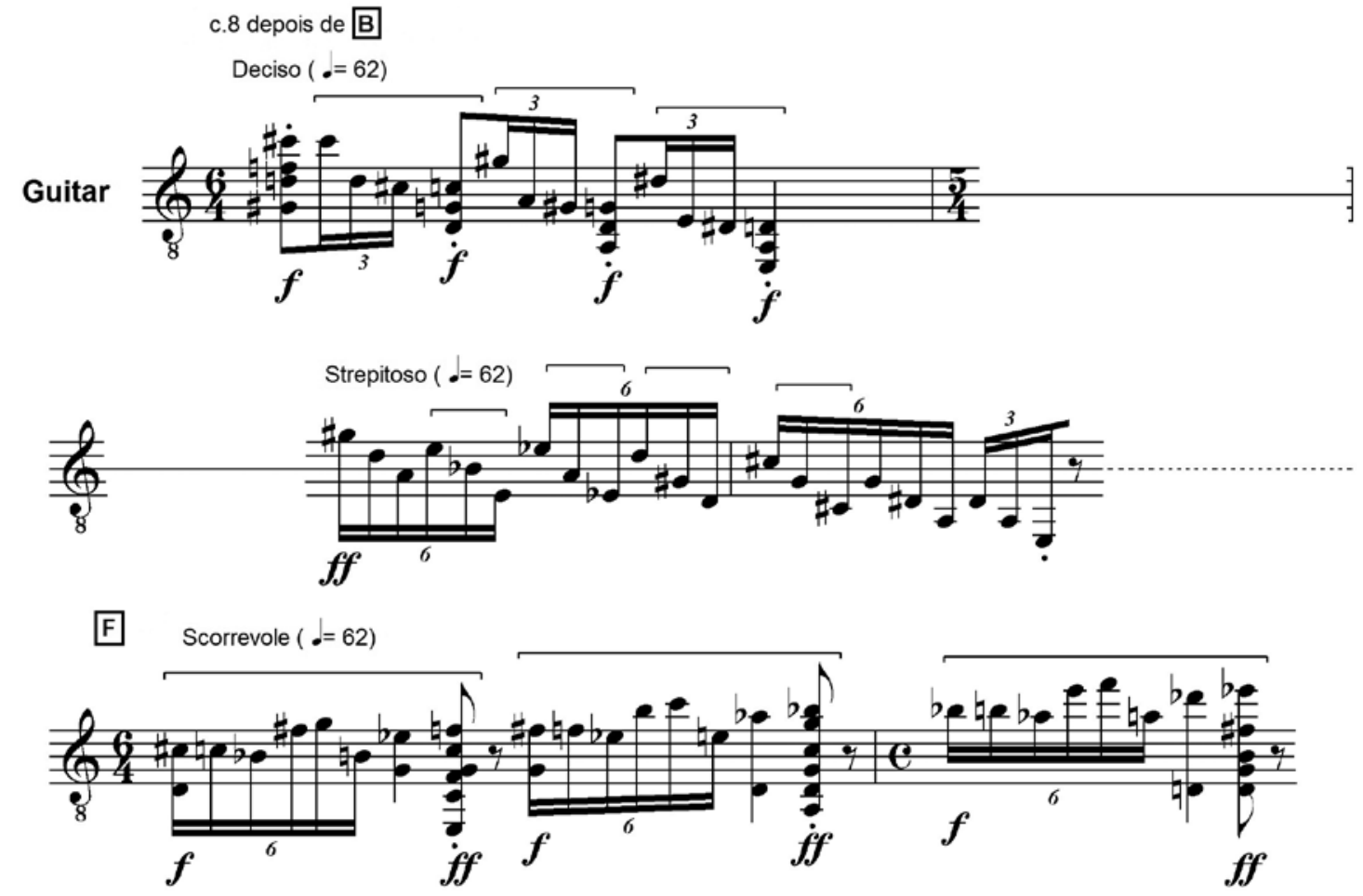

Ex.3. Emprego da sequência em relação de quarta justa e de semitom. (Portais e a Abside de Celso Loureiro Chaves)
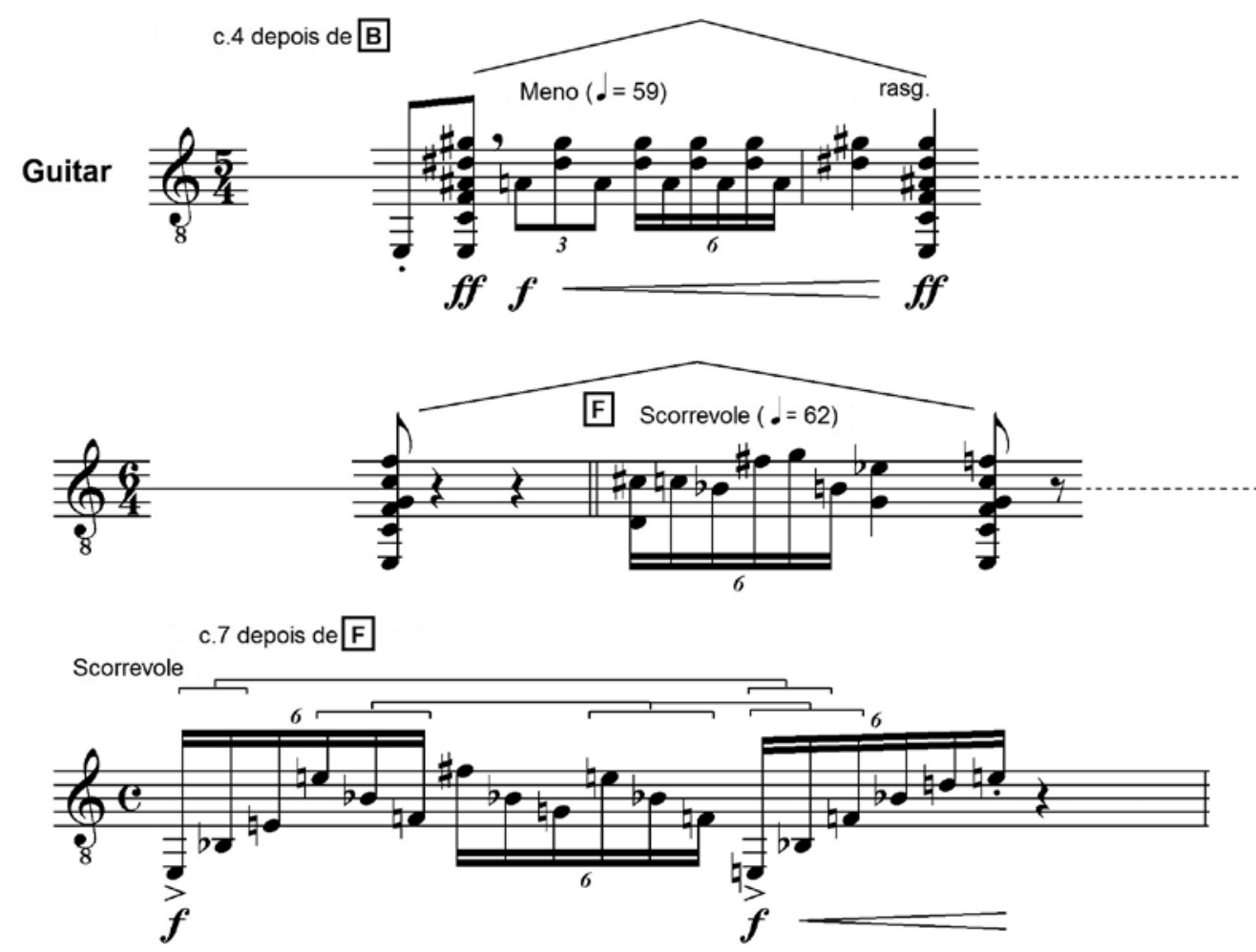

Ex.4. Aliteração: figura de linguagem, transposto o conceito para o discurso em música, que consiste na repetição de sonemas em uma frase musical. (Portais e a Abside de Celso Loureiro Chaves) 
Identifica-se a figura da sequência, Ex.3, principal articuladora do procedimento da modulação na música do último barroco.

Identificam-se, ainda, figuras da retórica - aliteração, Ex.4; diácope, Ex.5; anáfora, Ex.6; epizêuxis, Ex.7; pleonasmo como recurso de ênfase - estreitamente associadas à sintaxe da música modal e tonal. Figuras da retórica que hoje reconhecemos como dotadas da suficiente flexibilidade a nos permitir afastar 0 peso histórico e integrá-las em novos processos de significação.

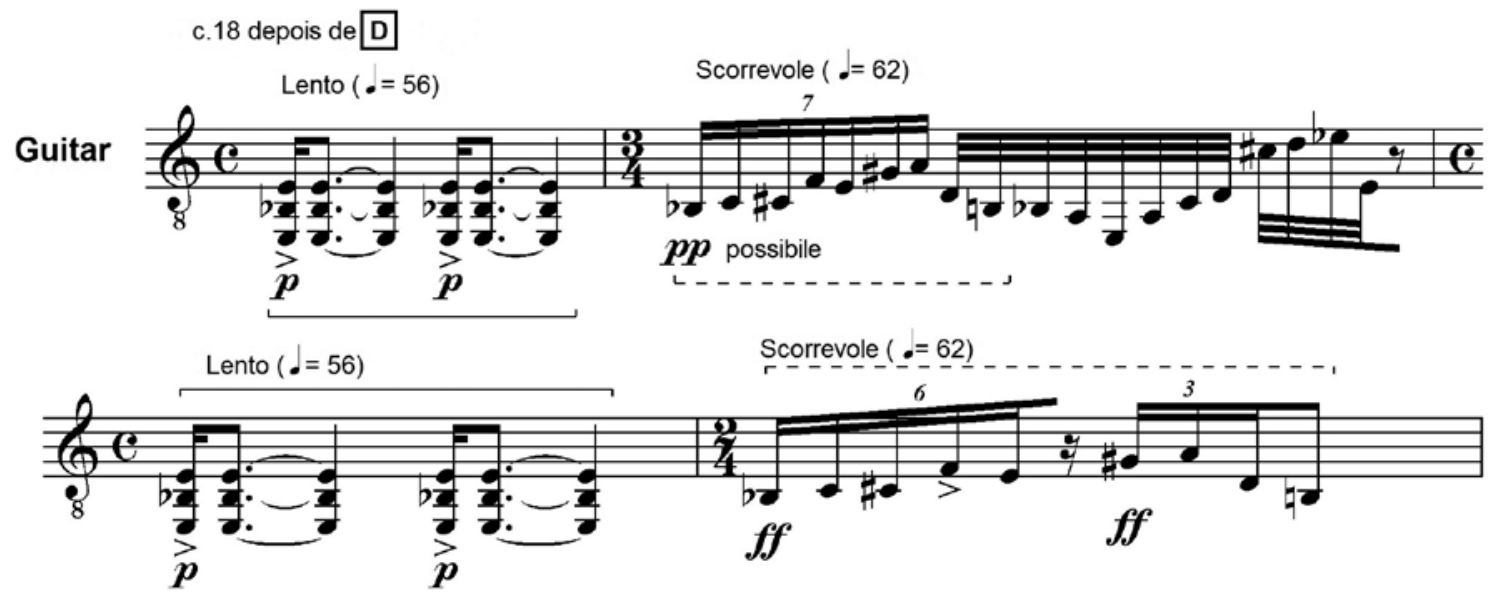

Ex.5. Diácope: figura de linguagem que consiste na repetição de um mesmo motivo, com a intercalação de outro distinto. (Portais e a Abside de Celso Loureiro Chaves)

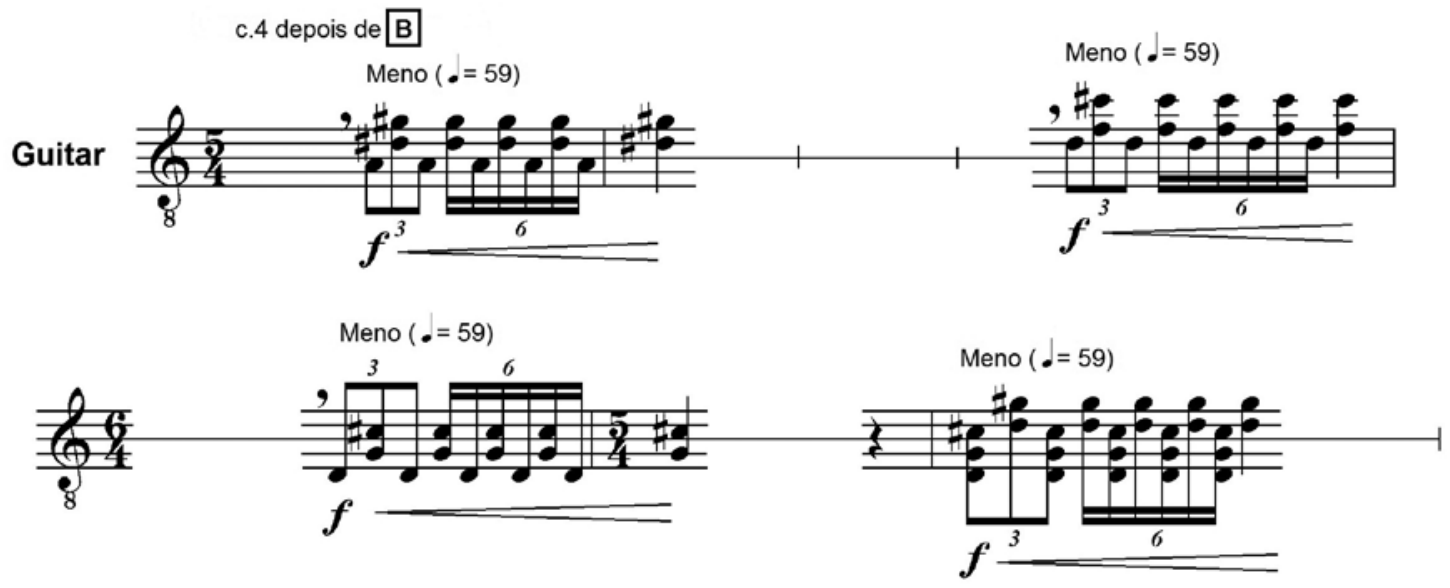

Ex.6. Anáfora: figura de linguagem que consiste na repetição do mesmo motivo no início de frases consecutivas. (Portais e a Abside de Celso Loureiro Chaves)

c.2 depois de B

Guitar

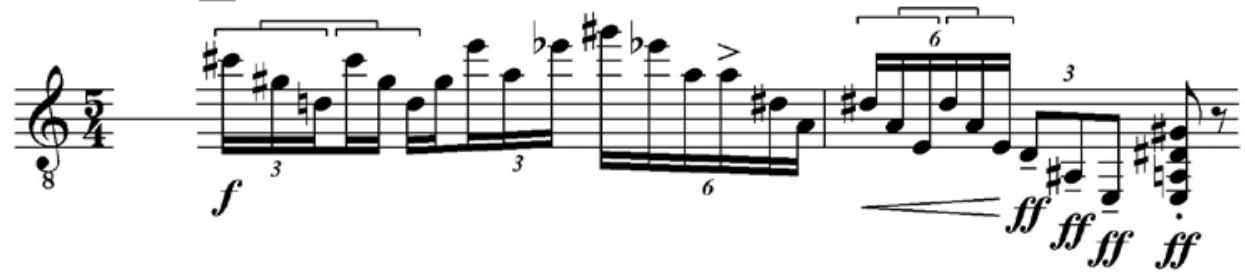

Ex.7. Epizêuxis: figura de linguagem que consiste na repetição imediata de um mesmo motivo.

(Portais e a Abside de Celso Loureiro Chaves) 
0 interesse pela retórica, assinalamos, está no modo sistematizado de lidar com a repetição ou a reiteração como instrumento de manipulação da ênfase, com repercussão direta nos valores expressivos. Estas ferramentas estruturantes - tema, motivo, elaboração, figuras da retórica - é que regem a percepção auditiva, a inteligibilidade do discurso e consequentemente articulam a forma musical em Portais e a Abside. Esta reunião da sistematização serial com elementos estruturantes retomados da tradição, chamados a atuar em novas relações sintáticas, é expressão da tendência predominante, a partir das últimas décadas do século $X X$, de superação da dicotomia vanguarda-tradição. Uma sintese indispensável para se seguir avançando, como o foi no final do barroco a síntese - operada, entre outras, na música de Bach e de Haendel - entre as técnicas polifônicas oriundas da música franco-flamenga e o pensamento harmônico desenvolvido a partir da "segunda prática", consolidado como sistema no Traité de I'harmonie, de Jean Philippe Rameau.

\section{6 - Tempo de síntese}

A construção que se alicerça em elementos que remetem a tradições distintas e que se pretenderam em oposição - 0 serialismo integral e as técnicas de elaboração da música modal e tonal - expõe os termos que marcam Portais e $a$ Abside, termos que habitam e condicionam tanto o interior da obra como a sua posição estética. Termos que marcam toda uma produção do final do século XX e início do século XXI como tendência a uma síntese. Portais e a Abside é expressão desta tendência à sintese entre as conquistas da vanguarda e as práticas consagradas da tradição. Apazigua elementos estruturantes considerados, por quase cinquenta anos, como excludentes, demarcadores da adesão do compositor aos vários "partidos" da música. Com este apaziguamento podemos, finalmente, deslocar, sem perdê-la de vista, o nosso foco de interesse da sintaxe musical para as questões - mais prementes, amplas, e de muito maior interesse - da significação, apontadas mesmo nos principais textos sobre a música de vanguarda, mas sempre de passagem, nunca desenvolvidas a não ser, de modo sucinto, ou pelo discurso da negação ou pelo discurso do entendimento e do acordo tácito. Não ignoramos os avanços e principalmente o ar viciado de permanente novidade em certa produção musical dos últimos quarenta anos. Não ignoramos os avanços trazidos pela música eletroacústica, beneficiada pelo extraordinário avanço tecnológico, mas Portais e a Abside, junto com a produção mais significativa dos últimos vinte anos, mostram e demonstram que o tempo é de síntese.

\section{7 - Portais e a Abside: referência arquitetônica}

0 título de uma obra sempre guarda com esta uma relação de identidade e, por conseguinte, de identificação. É sinalizador do sentido da obra, seja este da forma, do conteúdo ou referencial, apontando para elementos exteriores à obra, que a esclarecem ou situam. 0 título Portais e a Abside remete à arquitetura religiosa. Refere-se a regiões específicas do templo. Os Portais separam o espaço profano do sagrado. São limítrofes, fronteiras indeléveis. A Abside, de extraordinária riqueza iconográfica, é o local da devoção, de onde o sacerdote conduz o rito. Ao transpor o Portal afastamonos do ruidoso e tumultuado espaço profano, que tem sua imagem sonora nos fortíssimos dos dois primeiros compassos, assim como no final "Deciso" [G] e "Animando" [H]. 0 título indica dois locais do templo, seus extremos, a música propriamente dita o percurso que leva de um ao outro e o retorno. 0 título Portais e a Abside, indicador dos locais demarcadores de um percurso, é assimilado na obra como a forma de um arco invertido. Deslocamo-nos da sonora fronteira entre o profano e o sagrado até as tranquilas sonoridades da seção central da peça - seção [D] - a expressão sonora do espírito de veneração, e de volta - a partir de [E] - para a fronteira entre o sagrado e o profano, para as figuras musicais tumultuadas, agitadas e ruidosas, fronteiriças da expressão da vida mundana. A obra apóia a sua direcionalidade neste percurso, e, ao mesmo tempo, torna-o pleno de significação. A seção central da obra, a Abside, é articulada por figuras em pedal, tal qual, permitimo-nos a analogia, o murmúrio de uma oração. A sensação da grandiosidade da presença divina que nos provoca o "campanário para o anjo", acima da Abside, é recriada pelo extenso registro estabelecido entre os sons graves dos pedais e os sons sobre-agudos dos harmônicos. A obra reconstrói a oposição entre 0 celestial e o terreno - transitório, inconstante, voltado para o imediato - que encontra a sua expressão sonora nas descontínuas e fragmentárias figuras em fusas e quiálteras de 5, 6 e 7 em semicolcheias.

\section{8 - 0 templo na ilha de Próspero}

Nas suas declarações, CHAVES (2005) se refere ao esquema formal como o "plano arquitetônico de um templo que poderia estar localizado na ilha de Próspero tal como desenhada por Peter Grennaway para o seu filme $A$ Última Tempestade". Este templo poderia, suposição nossa, estar localizado onde Greenaway indica "The Rheims Cathedral Maze", o que cria um fértil vínculo entre a concepção formal de Portais e a Abside e a arquitetura da catedral gótica de Notre-Dame de Reims, que tem como o ponto mais elevado o campanário para o anjo, acima da abside, expressão a um só tempo da grandiosidade de Deus e do ínfimo que é o ser humano diante da potência divina. Campanário que, como já foi dito, encontra a sua expressão musical na utilização, na seção central da obra, do mais extenso registro, das sonoridades mais graves - o terreno e humano - aos sobre-agudos harmônicos - o celestial e divino. A orientação da Catedral é singular, segundo o eixo Sudoeste-Nordeste, em linha com o solstício do verão, que ocorre, sempre, em 21 de junho. Para o mundo medieval, que construiu a catedral gótica de Notre-Dame de Reims, a luz é a própria expressão e sinal da presença divina. No solstício de verão, Deus, materializado em luz, se manifesta na sua forma mais intensa. A abside, local de veneração, é banhada, no solstício, da luz mais esplendorosa, da mais forte presença de Deus. É o pleno encontro daquele que venera com o venerado. É o símbolo do princípio de um 
novo ciclo: este o significado da orientação da Catedral em linha com o solstício de verão. Aqui reencontro a tese de que Portais e a Abside - junto a um conjunto importante de obras que inclui, por exemplo, Anthèmes, de Pierre Boulez; Licht, de Stockhausen; Carceri d'Invenzione, de Ferneyhough - traz em si o princípio de um novo ciclo, que se inicia com a sintese entre os avanços da vanguarda e as conquistas duradouras, resignificadas, da tradição. Esta tese é ainda reforçada simbolicamente pela inserção harmônica do vitral de Marc Chagal na catedral de NotreDame de Reims, instalado no eixo da abside em 1974. Há aqui um duplo sentido: o da obra de arte da vanguarda plenamente integrada ao universo gótico da Catedral, e a colaboração do judeu convicto que é Chagal à Catedral cristã. Sentidos que reforçam a ideia de síntese, de patamar para um novo avanço tanto da produção artística quanto das relações sociais.

\section{9 - Grande Sertão: Veredas}

Se Portais e a Abside, de acordo com CHAVES (2005), "reflete o plano arquitetônico de um templo que poderia estar localizado na ilha de Próspero", este templo poderia, também, supomo-lo, ter o seu sítio no Grande Sertão: Veredas, de Guimarães Rosa. É o projeto-pensamento de Riobaldo:

\begin{abstract}
Às vezes eu penso: seria o caso de pessoas de fé e posição se reunirem, em algum apropriado lugar, no meio dos gerais, para se viver só em altas rezas, fortíssimas, louvando a Deus e pedindo glória do perdão do mundo. Todos vinham comparecendo, lá se levantava enorme igreja, não havia mais crimes, nem ambição, e todo sofrimento se espraiava em Deus, dado logo, até à hora de cada uma morte cantar. (ROSA, 1983, p.44, negrito nosso)
\end{abstract}

Eu queria formar uma cidade da religião. Lá, nos confins do Chapadão, nas pontas do Urucúia. (ROSA, 1983, p.220)

Queria ver ainda uma igreja grande, brancas torres, reinando de alto sino, no estado do Chapadão. Como que algum santo ainda não há de vir, das beiras deste meu Urucúia? (ROSA, 1983, p.342)

0 que une Grande Sertão: Veredas, a Catedral de NotreDame de Reims, e Portais e a Abside, é a religiosidade em expressão múltipla e ampla, para além dos dogmas próprios de cada religião, que, no caso da Catedral de Notre-Dame de Reims, permitiu que ali se instalasse 0 vitral de Chagal, símbolo harmonioso e conciliador de dois dogmas muitas vezes proclamados irreconciliáveis. No caso de Portais e a Abside, é um templo sonoro que se materializa no percurso para uma região sonora de meditação, aberta a qualquer fé.

Grande Sertão: Veredas é narrado na primeira pessoa por Riobaldo, que é o sertão feito carne. Riobaldo explica:

Hem? Hem? 0 que mais penso, testo e explico: todo-o-mundo é louco. 0 senhor, eu, nós, as pessoas todas. Por isso é que se carece principalmente de religião: para se desendoidecer, desdoidar. Reza é que sara da loucura. No geral. Isso é que é a salvação-da-alma... Muita religião, seu moço! Eu cá, não perco ocasião de religião. Aproveito de todas. Bebo água de todo rio... Uma só, para mim é pouca, talvez não me chegue. Rezo cristão, católico, embrenho a certo; e aceito as preces de compadre meu Quelemém, doutrina dele, de Cardéque. Mas, quando posso, vou no Mindubim, onde um Matias é crente, metodista: a gente se acusa de pecador, lê alto a Bíblia, e ora, cantando hinos belos deles. (...)

Olhe: tem uma preta, Maria Leôncia, longe daqui não mora, as rezas dela afamam muita virtude de poder. Pois a ela pago, todo mês - encomenda de rezar por mim um terço, todo santo dia, e, nos domingos, um rosário. Vale, se vale. Minha mulher não vê mal nisso. E estou, já mandei recado para uma outra, do Vau-Vau, uma Izina Calanga, para vir aqui, ouvi de que reza também com grandes meremerências, vou efetuar com ela trato igual. Quero punhado dessas, me defendendo em Deus, reunidas de mim em volta... Chagas de Cristo! (ROSA, 1983, p.15)

Há em Riobaldo um sincretismo-síntese religioso, onde a dimensão ética - o bem e o mal - é dada pelo diabo, amplamente referenciado:

[...] o Arrenegado, o Cão, o Cramulhão, o Individuo, o Galhardo, o Pé-de-Pato, o Sujo, o Homem, o Tisnado, o Coxo, o Temba, o Azarape, o Coisa-Ruim, o Mafarro, o Pé-Preto, o Canho, o DubaDubá, o Rapaz, o Tristonho, o Não-sei-que-diga, 0-que-nunca-seri, o Sem-Gracejos [...] (ROSA, 1983, p.31).

A presença do Tinhoso, o mal, é localizada, em oposição à onipresença de Deus. 0 Bem e o Mal atuam, a um só tempo, em oposição e de modo complementar na moldagem do destino humano. Em oposição: "Senhor sabe: Deus é definitivamente; o demo é o contrário Dele..." Em complementaridade:

[...] a gente criatura ainda é tão ruim, tão, que Deus só pode às vezes manobrar com os homens é mandando por intermédio do diá? Ou que Deus - quando o projeto que ele começa é para muito adiante, a ruindade nativa do homem só é capaz de ver o aproximo de Deus é em figura do Outro? (ROSA, 1983, p.32, itálico do autor)

Mas o demônio não existe real. Deus é que deixa se afinar à vontade o instrumento, até que chegue a hora de se dançar. (ROSA, 1983, p.220)

Ao olhar para si mesmo, Riobaldo avalia: "Eu podia ser: padre sacerdote, se não chefe de jagunços; para outras coisas não fui parido". (ROSA, 1983, p.15) Estes extremos do possivel ser de Riobaldo - Portais-jagunçodemo e Abside-sacerdote-Deus - conciliam-se numa religiosidade que se aproveita de todas as religiões: "Bebo água de todo rio..." A religiosidade em Riobaldo, sintética, é um apaziguar: "Com Deus existindo, tudo dá esperança: sempre um milagre é possível, o mundo se resolve". (ROSA, 1983, p.46). Com Riobaldo encerra-se um ciclo. Riobaldo é sobrevivência de um sertão que se transfigurou. 0 sertão no agora de Riobaldo-velho é aquele que contempla o Doutor-leitor que ouve a narrativa: "E as ideias instruídas do senhor me fornecem paz".

Ao perseguir o sentido da declaração do compositor, não nos parece impróprio afirmar que, não somente a seção central, mas toda Portais e Abside "traz memória de alguma leitura longínqua da obra Grande Sertão: Veredas, de Guimarães Rosa". A oposição-complementaridade entre o profano e o sagrado, que Celso Loureiro Chaves constrói em Portais e a Abside, é da mesma natureza daquela que Guimarães Rosa constrói nas possibilidades do ser de Riobaldo: jagunço e sacerdote. 


\section{0 - Conclusão}

0 recurso a elementos extra-musicais, a intertextualidade - central no processo criativo de Portais e a Abside - exige que abordemos a questão da significação musical. A significação ${ }^{7}$, no seu sentido mais primário e abrangente, somente é possivel com o consequente uso pessoal de um significado resultado de um tácito acordo coletivo. A significação só se transmite por meio de um código, constituido empiricamente, compartilhado e dominado pelo emissor e o receptor. Essa a base da funcionalidade da linguagem. A linguagem artística pressupõe, entretanto, um ineditismo que extrapola a dimensão funcional da linguagem, que obriga a decifração num processo que exige do receptor uma extensão de suas referências, um ultrapassar e estender o seu conjunto de vivências sob o efeito da experiência com a obra de arte. A linguagem artística nos provoca, cobra-nos uma reação determinada pelo impacto da experiência com a obra e orientada pela reflexão crítica. A mensagem ${ }^{8}$ da obra de arte jamais se esgota na estreita apreciação hedonista. A mensagem somente se desvela, cada vez mais plena a cada aproximação, à medida que nos defrontamos com a infindável série de enigmas que a obra de arte nos propõe: enigmas que apontam tanto para a individualidade do artista quanto para a história específica da própria obra de arte e do momento histórico que a contém. História que inclui como aspecto mais significativo o seu pertencimento a um determinado e singular meio social. É imprescindível saber do contexto em que a obra foi criada, e, se possivel, buscar na genética da obra as referências, explícitas e implícitas, determinantes no seu processo de criação e na permanente construção do seu valor simbólico. As referências nas quais o compositor Celso Loureiro Chaves apoiou-se na composição de Portais e a Abside são, cada uma ao seu modo, expressão de síntese, de conciliação de opostos, e, ao mesmo tempo, indicativas da transição para um novo ciclo. São, podemos dizer, Portais. É preciso advertir e salientar que o recurso a referências extra-musicais atua como reforço, ênfase, iluminador de uma mensagem que já se transmite com toda a clareza exclusivamente pela manipulação da linguagem musical. Esta por si só - ao aproximar as técnicas seriais às figuras de construção da retórica e às ferramentas de organização consolidadas pela tradição da música ocidental - transmite ao ouvinte ciente do processo histórico da música a mensagem de que se encerra um período ao mesmo tempo em que se nos abre um novo ciclo do fazer musical.

\section{Referências:}

AGAWU, Kofi. How We Got Out of Analysis, and How to Get Back In Again. Music Analysis, Oxford UK, v.23 Issue 2-3, p.267-286, 2004.

BENT, Ian. Analysis. Grove Publications, 1987.

BOULEZ, Pierre. Apontamentos de Aprendiz. São Paulo: Editora Perspectiva, 1995. Tradução de MOUTINHO, Stella; PAGANO, Caio; BAZARIAN, Lídia.

CHAVES, Celso Giannetti Loureiro. Portais e Abside. Goldberg Edições Musicais, 1997.

. Portais e a Abside. Intérprete: Paulo Inda. In: Paulo Inda. I Paulo Inda. Porto Alegre: Secretaria Municipal da Cultura, FUMPROARTE, 2005. CD. Faixa XIV.

COOK, Nicholas. A Guide to Musical Analysis. R.S. Means Company, 1992.

DUNSBY, Jonathan e WHITTALL, Arnold. Music Analysis in Theory and Practice. Yale University Press, 1988.

FORTE, Allen. The Structure of Atonal Music. New Haven and London: Yale University Press, 1973.

KRAMER, Lawrence. Musical Meaning Toward a Critical History. Berkeley and Los Angeles: University of California Press, 2001. Music as Cultural Practice. Berkeley and Los Angeles: University of California Press, 1990. Musicology and Meaning. The Musical Times, v.144, n.1883, p.6-12, 2003.

NATIIEZ, Jean-Jacques. Etnomusicologia e significações musicais. Per Musi, Belo Horizonte, n.10, jul - dez, 2004, p. 5-30. NETTO, J. Teixeira Coelho. Semiótica, Informação e Comunicação. São Paulo: Editora Perspectiva, 1980.

ROSA, Guimarães. Grande Sertão: Veredas. São Paulo: Abril Cultural, 1983. (Publicado sob licença da Livraria José Olympio Editora S.A., Rio de Janeiro)

SCHAEFFER, Pierre. Traité des objets musicaux - essai interdisciplines. Editions du Seuil, 1966.

Tratado dos objetos musicais: ensaio interdisciplinar. Tradução de Ivo Martinazzo. Brasília: Editora Universidade de Brasilia, 1993.

SCHENKER, Heinrich. Five Graphic Music Analyses (Fünf Urlinie-Tafeln). New York: Dover Publications, Inc., 1969.

SCHOENBERG, Arnold. Style and Idea. Edited by Leonard Stein with translations by Leo Black. Berkeley and Los Angeles: University of California Press, 1984.

SUBOTNIK, Rose Rosengard. Developing variations: style an ideology in Western music. Minneapolis: University of Minnesota Press, 1990. 


\section{Notas}

1 La trosième impasse [de la musicologie] est celle du commentaire esthétique. Dans son ensemble, l'abondante littérature consacreé aus sonates, quatuors et symphonies, sonne creux. Seule l'habitude peut nous masquer la pauvreté et le caractère disparate de ces analyses. Lorsqu'on écarte, en amont et en aval de l'œuvre, les considérations complaisantes sur les états d'âme du compositeur ou ceux de l'exégète, on en est réduit à la plus sèche énumération, en termes de technologie musicale, de ses procédés de fabrication, ou, dans le meilleur des cas, à l'étude de sa syntaxe. Mais pas de véritable explication de texte. Peut-être n'y a-t-il pas lieu de s'en étonner? Peut-être la bonne musique étant en elle-même langage, et langage spécifique, échappe-t-elle radicalement à toute description et à toute explication au moyen des mots ? [En tout état de cause, nous nous bornerons à reconnaître que Le problème est assez important pour n'avoir pas à être camouflé, et que la difficulté n'a été ni résolument envisagée, ni clairement abordée.

L'analyse est sévère, sans doute, mais il nous faudra bien um jour ou l'autre prendre conscience de l'essoufflement de la musicologie qu'elle dénonce. Si toute explication se dérobe, qu'elle soit notionnelle, instrumentale ou esthétique,] mieux vaudrait avouer, somme toute, que nous ne savons pas grand-chose de la musique. Et, pis encore, que ce que nous en savons est de nature à nous égarer plutôt qu'à nous conduire. (SCHAEFFER, 1966, p.19-20)

2 For me, the notion of an intimate relationship between music and society [...] It is an idea that generates studies the goal of which (or at least one important goal of which) is to articulate something essential about why any particular music is the way it is in particular, that is, to achieve insight into the character of its identity.

3 The idea is to combine aesthetic insight into music with a fuller understanding of its cultural, social, historical, and political dimensions than was customary for most of the twentieth century.

4 Kramer explica a subjetividade como "o processo pelo qual uma pessoa ocupa uma série de posições socialmente definidas, a partir das quais certas formas de ação, desejo, fala, e compreensão tornam-se possiveis." (KRAMER, 2003, p.6, tradução nossa)

5 [...] it seems fair to say that cultural musicology is above all a continuing effort to understand musical subjectivity in history.

6 Ver SCHOENBERG (1984), Style and Idea, Part V - Twelve-Tone Composition, especialmente 'Schoenberg's Tone-Rows' (1936) e Composition with Twelve Tones (1941).

7 Emprego "significação" no sentido que encontro em NETTO (1980, p.22-23): "A significação de um signo não deve ser confundida com o significado desse mesmo signo. 0 significado é o conceito ou imagem mental que vem na esteira de um significante, e significação é a efetiva união entre um certo significado e um certo significante. Se se preferir, pode-se dizer que a questão do significado está no domínio da língua, e da significação, no da fala. Em outras palavras, a significação de um signo é uma questão individual, localizada no tempo e no espaço, enquanto o significado depende apenas do sistema e, sob este aspecto, está antes e acima do ato individual. (...) a significação é uma questão fenomenológica, só sendo passível de delimitação e descrição numa manifestação concreta e isolada".

8 Abraçamos o princípio geral proposto por NATTIEZ $(2004$, p.20) para explicar o fenômeno da semantização: "O ser humano pode associar, em razão de uma analogia natural e motivada entre o significante musical e o significado ao qual remete, pelo efeito quer de uma convenção, quer de uma codificação sociocultural, ou ambos, um fenômeno musical qualquer (alturas, intervalos, esquemas rítmicos, escalas, acordes, motivos, frases musicais, melismas, instrumentos, etc.) com um fragmento qualquer de sua existência no mundo (afetivo, psicológico, social, religioso,metafísico, filosófico, etc.), em função de suas necessidades (religiosas, alimentares, ecológicas,econômicas, lúdicas, afetivas, etc.) e segundo as capacidades simbólicas próprias da música." 0 conceito de mensagem, como o entendemos e empregamos, é parte do fenômeno de semantização.

Flavio Santos Pereira é professor da Universidade de Brasília - UnB desde 1990. Sua obra Sistema II, para flauta solo, está gravada por Wilson Holanda, pelo projeto PROMEMUS/FUNARTE; Preludio, para piano, está registrada no CD Compositores, pela Universidade de Brasilia, por Patrícia Vanzella. Suas obras foram selecionadas em diversas edições da Bienal de Música Brasileira Contemporânea. As Três canções sobre textos de Fernando Pessoa, para voz feminina e piano, foram estreadas na XVIII Bienal por Maíra Lautert e Priscila Bonfim. Atualmente cursa o doutorado em composição na Universidade Federal do Rio Grande do Sul - UFRGS, com bolsa do CNPO. 